\title{
ALTERNATIF SOLUSI MODEL PEMBELAJARAN UNTUK MENGATASI RESIKO PENURUNAN CAPAIAN BELAJAR DALAM PEMBELAJARAN TATAP MUKA TERBATAS DI MASA PANDEMIC COVID 19 (STUDI KASUS ANALISIS KEBIJAKAN PENDIDIKAN)
}

\author{
${ }^{1}$ Novita Sari Tanuwijaya, ${ }^{2}$ Witarsa Tambunan \\ 1,2Magister Administrasi Pendidikan PPs-UKI, Jakarta, Indonesia \\ e-mail: witarsa.oke@gmail.com
}

\begin{tabular}{l|l|l} 
Received : April, 2021 & Accepted : April, 2021 & Published : Juli, 2021
\end{tabular}

\begin{abstract}
Pandemic Covid 19 that has been occurred provides challenges in various sector of our life, also in education. To face these challenges, the government issued several policies in the education sector. Eductaional Policies in the learning process during this pandemic have undergone several changes / adjustments to overcome problems that arising from the previous policy. Even the current policy, through a 4 ministerial decree, by allowing limited face-to-face / offline schools has the potential to cause problems too. In this study the author intends to examine one of the potential problems that might arise with the offline school policy. Where due to limitations in the delivery of material, there is a potential for a decrease in learning outcomes. Through a qualitative descriptive study by examining several sources of government policies and literature review, the authors will explore how alternative solutions can be made to anticipate these problems. From the results of problem identification and mapping of alternative solutions using the problem tree method, it was found that the blended learning process could reduce the potential for a decrease in learning outcomes due to limitations in the delivery of learning material in offline learning.
\end{abstract}

Keyword: pandemic covid 19, government policies, offline learning, blended learning

\begin{abstract}
Abstrak
Pandemi covid 19 yang terjadi memberikan banyak tantangan dalam kehidupan, termasuk dalam dunia pendidikan. Sebagai upaya menghadapi tantangan tersebut pemerintah mengeluarkan beberapa kebijakan di bidang pendidikan. Kebijakan pemerintah di bidang pendidikan mengenai proses pembelajaran di masa pandemi ini sempat mengalami beberapa kali perubahan/penyesuaian kebijakan sebagai upaya mengatasi permasalahan yang timbul dari kebijakan sebelumnya. Kebijakan yang diambil saat ini pun, melalui SKB 4 menteri, dengan mengizinkan sekolah tatap muka/offline terbatas pun berpotensi menimbulkan masalah. Dalam penelitian ini akan dikaji salah satu potensi masalah yang mungkin akan timbul dengan adanya kebijakan sekolah offline. Dimana dikarenakan keterbatasan dalam penyampaian materi maka ada potensi penurunan capaian hasil pembelajaran. Melalui kajian secara deskriptif kualitatif dengan mengkaji beberapa sumber kebijakan pemerintah dan kajian literatur maka akan digali bagaimana alternatif solusi yang dapat dilakukan untuk mengantisipasi permasalahan tersebut. Dari hasil identifikasi masalah dan pemetaan alternative solusi dengan menggunakan metode pohon masalah didapatkan bahwa proses pembelajaran "blended learning" dapat mengurangi
\end{abstract}


potensi penurunan capaian hasil belajar yang diakibatkan karena keterbatasan dalam penyampaian materi pembelajaran di pembelajaran offline.

Kata Kunci: pandemic covid 19, kebijakan pemerintah, tatap muka/offline, blended learning \begin{tabular}{l}
\hline Citation: Tanuwijaya, N. S., \& Tambunan, W. (2021). ALTERNATIF SOLUSI MODEL PEMBELAJARAN \\
UNTUK MENGATASI RESIKO PENURUNAN CAPAIAN BELAJAR DALAM PEMBELAJARAN TATAP \\
MUKA TERBATAS DI MASA PANDEMIC COVID 19: (STUDI KASUS ANALISIS KEBIJAKAN \\
PENDIDIKAN).Jurnal Manajemen Pendidikan, 10(2), $80-90$. \\
http://ejournal.uki.ac.id/index.php/jmp/article/view/3272
\end{tabular}

\section{PENDAHULUAN}

Sudah lebih dari satu tahun pandemi korona melanda negara kita. Sejak awal pandemic terjadi, berbagai upaya dilakukan untuk menanggulangi penyebaran virus ini. Pemerintah mengeluarkan beberapa kebijakan untuk menanggulanginya, termasuk di sector pendidikan. Kebijakan yang diambil pemerintah di awal pandemic di bidang pendidikan tertuang dalam surat edaran Direktorat Jenderal Pendidikan Tinggi Kementerian Pendidikan dan Kebudayaan Nomor 1 Tahun 2020 Tentang Pencegahan Penyebaran Corona Virus Disease (Covid-19) di Perguruan Tinggi (2020). Dalam Surat edaran ini kemendikbud menetapkan pembelajaran jarak jauh menjadi metode pembelajaran yang disarankan kepada mahasiswa dengan menyesuaikan kondisi perguruan tinggi masing-masing.

Selain kebijakan tersebut, kemendikbud melalui surat edaran nomor 4 tahun 2020 juga mengeluarkan pelaksanaan kebijakan pendidikan dalam masa darurat penyebaran virus korona. Kebijakan yang merupakan langkah strategis yang diambil di masa darurat covid ini berisi 6 hal antara lain menyangkut ujian nasional, proses belajar dari rumah, dana bantuan operasional sekolah. Untuk memperkuat Surat Edaran Mendikbud Nomor 4 Tahun 2020, kemendikbud mengeluarkan Surat Edaran Nomor 15 ini tentang Pelaksanaan Pendidikan Dalam Masa Darurat Coronavirus Disease (Covid-19). Dalam surat edaran ini disebutkan bahwa tujuan dari pelaksanaan Belajar Dari Rumah (BDR) adalah memastikan hak siswa dalam memperoleh pelayanan pendidikan tetap dapat dipenuhi, anggota dari unit pendidikan terlindungi dari akibat negatif Covid-19, menjaga agar covid 19 tidak tersebar dan menular di unit pendidikan dan menjamin terpenuhinya support psikososial bagi pendidik/guru, siswa dan orang tua..

Untuk mempermudah pengintrepertasian kebijakan tersebut, pemerintah (kemendikbud) mengeluarkan Buku Saku Panduan Penyelenggaraan Pembelajaran Pada Tahun Ajaran 2020/2021 dan Tahun Akademik 2020/2021 Di Masa Pandemi Coronavirus Disease 2019 (Covid-19) (Kemendikbud, 2020). Panduan ini menjadi acuan pemerintah daerah dalam pengaturan unit pendidikan dan diharapkan memudahkan masyarakat dari berbagai kalangan untuk memahami panduan yang dituangkan dalam Surat Keputusan Bersama (SKB) 4 Menteri dan lampirannya.

SKB 4 Menteri pertama kali diterbitkan pada tanggal 15 Juni 2020 yang mengizinkan Sekolah di Zona Hijau untuk memulai pembelajaran tatap muka terbatas, sementara sekolah yang berada pada Zona Kuning, Oranye, dan Merah tetap memberlakukan Belajar Dari Rumah (BDR). Penyelenggaraan proses belajar tatap muka di zona hijau diijinkan namun harus mengikuti aturan protokol kesehatan yang ketat dan harus ditetapkan dengan keputusan dari Gugus Tugas Covid-19 sesuai masing-masing daerah.

Dalam pengaplikasiannya, ternyata pembelajaran jarak jauh melalui berbagai media yang tersedia memberikan efek yang beragam, ada beberapa kendala yang dihadapi oleh guru, orang tua, dan siswa dalam pelaksanaan aktivitas PJJ. Kendala yang terjadi apabila tidak segera ditangani maka 
dapat mengakibatkan timbulnya efek negatif jangka panjang seperti menurunnya prestasi belajar siswa, maupun resiko kekerasan pada anak dan bahkan hingga berdampak pada keberlangsungan sekolah dari siswa. Untuk menjawab permasalahan ini maka SKB 4 Menteri ini mengalami revisi kebijakan. Pemerintah melakukan revisi kebijakan per Agustus 2020. Dimana semula hanya Zona Hijau yang diijinkan melakukan pembelajaran tatap muka, diperluas ke Zona Kuning juga bisa melakukan pembelajaran tatap muka.

Walaupun pembelajaran di zona kuning dan zona hijau sudah diijinkan namun masih banyak satuan pendidikan yang tetap belajar dari rumah. Pemerintah menyadari bahwa semakin lama pembelajaran tatap muka tidak terjadi semakin memberikan dampak negatif bagi peserta didik. Beberapa dampak yang dapat terjadi seperti ancaman putus sekolah, kendala tumbuh kembang dimana terdapat perbedaan akses kualitas selama PJJ yang mengakibatkan kesenjangan capai belajar (Kemdikbud, 2020). Untuk mengatasi permasalahan tersebut, pemerintah kembali melakukan penyesuaian kebijakan untuk memberikan penguatan kepada pemerintah daerah/kanwil/kantor kemenag. SKB 4 menteri yang dikeluarkan di bulan Agustus 2020 mengalami revisi pada bulan November 2020 sebagai panduan untuk semester genap tahun pelajaran 2020/2021. Kebijakan ini memberikan kewenangan kepada Pemerintah Daerah untuk melaksanakan pembelajaran tatap muka dengan prosedur ketat yang sesuai standar protokol kesehatan. Kebijakan ini diambil dengan pertimbangan bahwa penentuan kebijakan pembelajaran harus disesuaikan dengan konteks dan kebutuhan masing-masing daerah karena kondisi, kebutuhan dan kapasitas tiap-tiap daerah bisa berbeda-beda antara satu dengan lainnya. Apakah kebijakan untuk sekolah tatap muka terbatas ini merupakan solusi terbaik dan apakah ada potensi masalah yang dapat terjadi dalam pembelajaran ini? Bagaimana alternative solusi untuk dapat mengatasinya?

Kebijakan pendidikan merupakan rangkaian dari kata "kebijakan" dan "pendidikan". Menurut Suhelayanti (2019) kebijakan sendiri dihasilkan dari keputusan yang dilakukan oleh manajemen puncak dimana pembuatannya dilakukan secara berhati-hati berintikan sejumlah tujuan, prinsip, dan peraturan untuk membimbing suatu organisasi. Sementara menurut Syarafudin dalam Purba, S., dkk (2021) kebijakan terkait dengan gagasan dalam mengatur organisasi yang polanya bersifat formal dan diterima oleh pemerintah/lembaga sebagai acuan untuk mengejar tujuan bersama. Dikatakan oleh Koontz, dkk dalan Purba, S., dkk (2021) bahwa ada batas-batas dalam pengambilan keputusan yang dituntut oleh sebuah kebijakan. Jadi kebijakan merupakan petunjuk atau batasan yang menjadi arah dari tindakan yang berisi tujuan, prinsip dan peraturan yang harus diikuti oleh para pelaku dan pelaksana kebijakan.

Sebuah kebijakan harus memuat langkah strategis yang menjadi acuan dalam berpikir dan bertindak untuk mencapai tujuan bersama dan harus sejalan dan dijabarkan dari visi, misi serta tujuan dari organisasi tersebut yang telah ditetapkan sebelumnya dan berlaku untuk kurun waktu tertentu. Kebijakan itu sejalan dengan visi dan tujuan dari sebuah organisasi namun kurun waktunya relative lebih pendek. Kebijakan dapat berubah disesuaikan dengan kondisi dan situasi yang terjadi saat itu. Dalam prakteknya kebijakan itu dapat mengalami perubahan, perubahan dari sebuah kebijakan yang satu dan yang lain membutuhkan proses pengkajian atau penelaahan terhadap situasi dan kondisi yang terjadi. Dalam dunia pendidikan, analisis kebijakan pendidikan penting untuk memahami dan memperbaiki kebijakan yang ada sebelumnya. Apabila hasil analisis menunjukan konsekuensi yang belum atau sudah tidak sesuai dengan rencana yang diharapkan maka kebijakan tersebut dapat mengalami perubahan. Di masa pandemi ini berbagai kebijakan di bidang pendidikan yang menyangkut proses pembelajaran diambil pemerintah untuk menanggulangi penyebaran virus korona.

Di awal pandemic, kebijakan pembelajaran jarak jauh diambil dan diharapkan menjadi solusi masalah penyebaran virus corona dalam lingkungan pendidikan dikarenakan karena melalui proses belajar mengajar online maka dapat diaplikasikan kebijakan "social distancing" sehingga dapat mendukung pencegahan menyebarnya virus corona (Handarini, 2020). Interaksi dilakukan secara virtual dengan memanfaatkan teknologi sehingga dapat berlangsung interaksi dan transfer ilmu dari pendidik ke peserta didik/pembelajar. Pembelajaran jarak jauh merupakan jalan keluar 
dalam menghadapi hambatan pembelajaran melalui tatap muka. Semua pihak dan tingkat pendidikan ditantang bagaimana menjaga aktivitas kelas walaupun tidak di sekolah (Herliandry, Nurhasanah , \& Enjelina, 2020). Dalam pembelajaran jarak jauh peserta didiknya tidak berinteraksi langsung secara fisik dengan pendidik dalam proses pembelajaran jarak jauh yang dilangsungkan (Latip, 2020). Perubahan proses pembelajaran. yang sebelumnya dilakukan di kelas melalui tatap muka langsung menjadi jarak jauh, memberikan tantangan bagi semua pihak yang terlibat dalam aktivitas pendidikan. Dalam pengaplikasiannya, ternyata pembelajaran jarak jauh melalui berbagai media yang tersedia memberikan efek yang beragam. Di dalam dokumen penyesuaian kebijakan pembelajaran di masa pandemic covid 19 yang dikeluarkan kemendikbud (Kemendikbud, 2020), disampaikan bahwa ada beberapa kendala yang dihadapi oleh guru, orang tua, dan siswa. Guru mengalami kendala dalam pengelolaan aktivitas PJJ. Sementara orang tua terkendala dalam membagi waktu untuk mendampingi anak belajar di rumah dan bagaimana memberikan motivasi kepada anaknya. Siswa pun juga mengalami kendala seperti kesulitan berkonsesntrasi saat BDR dan meningkatnua rasa stress dan jenuh akibat isolasi yang cukup lama yang berpotensi menimbulkan kecemasan dan depresi. (Kemendikbud, 2020).

Untuk menjawab permasalahan ini maka SKB 4 Menteri ini mengalami revisi kebijakan. Pemerintah melakukan revisi kebijakan per Agustus 2020. Dimana semula hanya Zona Hijau yang dijinkan melakukan pembelajaran tatap muka, diperluas ke Zona Kuning juga bisa melakukan pembelajaran tatap muka. Kebijakan yang diambil ini pun dianggap masih mengalami beberapa kendala yang semakin memberikan dampak negatif bagi peserta didik. SKB 4 menteri yang dikeluarkan di bulan Agustus 2020 inipun mengalami revisi pada bulan November 2020 sebagai panduan untuk semester genap tahun pelajaran 2020/2021. Apabila sebelumnya izin sekolah tatap muka masih melihat zona, maka dalam SKB ini Pemerintah Daerah diberi kewenangan untuk melaksanakan pembelajaran tatap muka dengan prosedur ketat yang sesuai standar protokol kesehatan. Perubahan dalam proses pembelajaran dari offline menjadi online dan kini offline tentunya memerlukan penyesuaian. Dan merupakan hal yang perlu dipersiapkan dengan matang mengingat proses pembelajaran akan memepengaruhi output atau hasil capaian pembelajaran siswa.

Proses pembelajaran sendiri merupakan salah satu standar dalam Standar Nasional Pendidikan Indonesia. Standar yang digunakan dalam menjamin mutu pendidikan di Indonesia adalah Standar Nasional Pendidikan (SNP) yang berisi 8 standar yang dijabarkan dalam beberapa indikator dan sub indicator. Ke delapan nya saling bersinergi satu sama lain sebagai input, proses dan output yang dihasilkan. Standar Kompetensi Lulusan merupakan output yang akan terpenuhi apabila input terpenuhi sepenuhnya dan proses berjalan dengan baik. Standar yang menjadi input dan proses memiliki hubungan sebab-akibat dengan output. Standar dijabarkan dalam bentuk indikator mutu untuk mempermudah kegiatan pemetaan mutu dalam penjaminan mutu sebagaimana digambarkan dalam bagan di gambar 1.1. (Dirjend, Pend dasar Menengah, 2017)

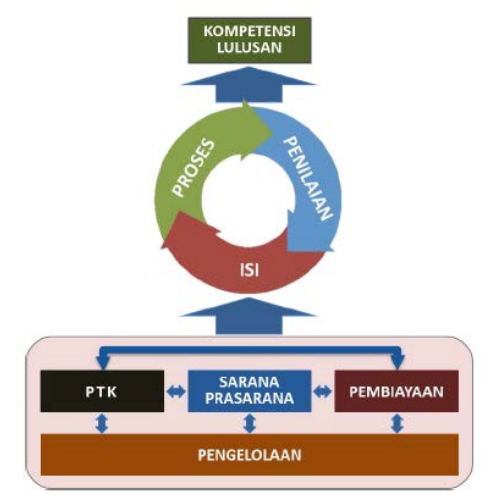

Gambar 1.1. Skema Standar Nasional Pendidikan (2017)

Dapat dilihat pada skema bahwa sebagai input terdapat standar pendidik dan tenaga kependidikan, sarana prasarana, pembiayaan dan pengelolaan, Sementara di dalam standar proses, ada 3

Novita Sari Tanuwijaya, Witarsa Tambunan 
indikator utama yang harus dipenuhi yaitu proses, isi dan penilaian. Indikator tersebut dijabarkan menjadi beberapa sub indicator lagi, seperti standar proses dijabarkan menjadi beberapa sub indicator terkait pelaksanaan proses pembelajaran yang salah satunya adalah bagaimana penerapan metode pembelajaran sesuai karakteristik siswa dan bagaimana pemanfaatan media pembelajaran untuk peningkatan efisiensi dan efektivitas pembelajaran. Apabila dikaitkan dengan perubahan-perubahan proses pembelajaran dimana kebijakan terbaru memungkinkan jika sebelumnya pembelajaran secara online (daring) maka maka sekarang sudah diizinkan untuk tatap muka terbatas. Maka untuk dapat menyesuaikan proses pembelajaran ini perlu dilakukan persiapan terhadap sarana dan prasarana sekolah sebagaimana yang disyaratkan oleh pemerintah yaitu: pembelajaran tatap muka dilakukan dengan tetap mengikuti protokol kesehatan yang ketat yang ditetapkan oleh kemendikbud baik itu terkait kondisi kelas, jadwal pembelajaran, perilaku wajib, kondisi dari warga satuan pendidikan, kantin, kegiatan olah raga dan ekstrakurikuler, maupun kegiatan selain pembelajaran dan pembelajaran diluar lingkungan satuan pendidikan.

Di masa pandemic ini kebijakan yang diambil pemerintah beberapa kali mengalamai penyesuian dikarenakan ada masalah yang timbul atau dampak negative ynag ditimbulakan dari kebijakan yang diambil. Kebijakan yang baru dikeluarkan melalui SKB 4 menteri di bulan November 2020 yang mengizinkan sekolah mengadakan pertemuan tatap muka terbatas diharapkan dapat menjawab permasalahan yang timbul selama pembelajaran jarak jauh. Namun pada kenyataannya kebijakan pembelajaran untuk semester genap tahun pelajaran 2020/2021 ini banyak menuai kontroversi baik itu dari pihak sekolah, siswa, maupun orang tua murid. Banyak orang tua yang belum mengizinkan anaknya mengikuti aktivitas pembelajaran tatap muka (offline) di sekolah karena masih merasa khawatir akan sangat berisiko jika siswa dibiarkan masuk kelas offline dalam kondisi saat ini. Kepala SMP di Jayapura dalam situs BBC News (2021) juga menyampaikan bahwa sesuai arahan Direktur Yayasan nya se-Kota dan Kabupaten Jayapura, semua sekolah Yayasan Katolik di dua daerah ini akan tetap melangsungkan proses pembelajaran secara daring. Hal tersebut dikarenakan tingkat penyebaran Covid-19 yang tinggi di Kota dan Kabupaten Jayapura sehingga ada kekhawatiran sekolah nanti menjadi klaster baru lagi. Selain itu SMP ini belum siap menggelar aktivitas belajar-mengajar tatap muka karena walaupun infrastruktur sudah lengkap semua, namun ada kendala terkait ketersediaan air karena PDAM ini tidak setiap hari mengalir.

Selain kendala tersebut, dalam uji coba penerapan yang pernah dilakukan, berdasarkan sumber berita dalam artikel di KompasTV Jawa Timur (2020) mengenai Uji Coba sekolah tatap muka di salah satu SMK di Jawa Timur terdapat kendala dalam pelaksanaannya. Disampaikan dalam berita tersebut bahwa aktifitas tatap muka terbatas (offline) yang dilakukan di SMK tersebut mengalami kendala diantaranya terkait ketidaktercapaian materi pelajaran dengan baik kepada anak didik, mengingat jumlah tatap muka hanya sekali dalam sepekan selama 4 jam dengan 4 materi pelajaran. Jumlah jam tatap muka terbatas harus dilakukan dalam upaya mematuhi persyaratan dari pemerintah mengenai protocol kesehatan yang harus dipenuhi dalam pertemuan tatap muka terbatas ini dimana kondisi kelas harus memenuhi jaga jarak minimal 1,5 meter, jumlah maksimal peserta didik per ruang kelas jenjang pendidikan anak usia dini (PAUD ) 5 (dari standar 15), peserta didik jenjang pendidikan dasar dan menengah 18 peserta didik (dari standar 36), Sekolah Luar Biasa (SLB) 5 peserta didik (dari standar 8), jadwal pembelajaran dilakukan dengan sistem bergiliran rombongan belajar (shifting) sesuai ketentuan dari masing-masing satuan pendidikan.

Dengan sistem bergiliran rombongan belajar (shifting) dan pembatasan jumlah maksimal peserta didik per ruang kelas ini mengakibatkan keterbatasan jam belajar siswa dalam pertemuan tatap muka offline di sekolah. Hal ini akan menimbulkan kendala terkait ketidakcapaian materi jam belajar. Ketidak tercapaian materi belajar tentunya akan berdampak dan mempengaruhi kompetensi siswa yang dihasilkan, apabila tidak segera ditangani maka akan berpotensi menyebabkan penurunan capaian belajar. Berdasarkan hal ini maka dapat dilihat bahwa kebijakan yang baru diambil juga memiliki ancaman potensi masalah yang dapat terjadi. Oleh karena itu, pada kesempatan kali ini akan dikaji mengenai pontensi masalah atau ancaman yang dapat terjadi saat melakukan pertemuan tatap muka terbatas dan memetakan alternative solusi untuk mengantisipasi persoalan yang dapat timbul. Potensi masalah yang akan dibahas disini dibatasi 
mengenai resiko penurunan capaian belajar yang berdampak pada kompetensi atau mutu lulusan. Ruang Lingkup dalam penelitian ini adalah: apakah akar penyebab dari menurunnya capaian belajar selama kegiatan sekolah offline atau tatap muka terbatas? Dan bagaimana alternatif solusi yang dapat dilakukan untuk mengatasi akar penyebab masalah tersebut?

\section{METODE PENELITIAN}

Untuk dapat mencari akar penyebab dari potensi permasalahan tersebut, maka dilakukan kajian deskriptif kualitatif dengan mengkaji beberapa sumber kebijakan pemerintah dan kajian literatur maupun berita yang berasal dari sumber berita media massa terpercaya. Hasil kajian yang didapat menjadi bahan untuk mencari akar penyebab dan menggali bagaimana alternatif solusi yang dapat dilakukan untuk mengantisipasi permasalahan tersebut. Identifikasi masalah dan pemetaan alternative solusi dilakukan dengan menggunakan metode analisis pohon masalah. Analisis pohon masalah merupakan suatu alat atau teknik atau pendekatan untuk mengidentifikasi dan menganalis masalah dengan cara menggambarkan rangkaian hubungan sebab akibat dari beberapa faktor yang saling terkait yang umumnya digunakan pada tahap perencanaan (Asmoko, 2012). Melalui metode ini maka akan membantu dalam merumuskan penyebab utama dari suatu permasalahan dan bagaimana alternative solusi yang dapat dilakukan.

Dalam penyusunan pohon masalah langkah pertama yang dilakukan adalah mengidentifikasi dan merumuskan masalah utama berdasarkan hasil analisis atas informasi yang tersedia. Setelah didentifikasi akibat yang akan muncul maka selanjutnya dilakukan analisis penyebab munculnya masalah utama. Penyebab pada tahap ini kita namakan penyebab level pertama. Setelah dipetakan penyebab level pertama dicari penyebab utama nya. Sumber masalah, akibat dan penyebab yang ditimbulkan apabila dipetakan maka akan dapat disusun pohon masalah secara keseluruhan. Setelah dilakukan analisis pohon masalah kemudian dilakukan identifikasi sasaran yang ingin diwujudkan melalui pohon sasaran. Pohon sasaran merupakan rangkaian sebab akibat yang pernyataannya merupakan kebalikan dari pernyataan pada pohon masalah. Dari analisi pohon masalah dan pohon sasaran yang telah disusun, untuk mewujudkan sasaran tersebut maka dilakukan identifikasi alternatif-alternatif pemecahan atau tindakan yang dapat diambil untuk mewujudkan sasaran tertentu dan memetakan informasi ini ke dalam pohon alternative.

\section{HASIL DAN PEMBAHASAN}

Sebagaimana yang telah disampaikan di bagian sebelumnya masalah utama yang dibahas adalah terkait isu sekolah tatap muka terbatas (offline) dimana ada potensi menurunnya capaian belajar selama kegiatan tatap muka terbatas. Setelah ditentukan masalah utama yang akan dikaji, akan dilakukan analisis akibat dan penyebab-penyebab dari masalah utama yang telah dirumuskan sebelumnya. Sesuai dengan standar nasional pendidikan, capaian pembelajaran merupakan bagian dari standar proses yaitu standar penilaian yang akan mempengaruhi mutu lulusan (Dirjend , Pend dasar Menengah, 2017). Sehingga menurunnya capaian belajar selama Pandemi covid 19 akan berakibat pada menurunnya kompetensi siswa. Setelah didentifikasi akibat yang akan muncul maka selanjutnya dilakukan analisis potensi penyebab munculnya masalah utama. Penyebab pada tahap ini kita namakan penyebab level pertama. Untuk mengidentifikasikan potensi penyebab maka dilakukan berdasarkan korelasi dalam fungsi berikut: 


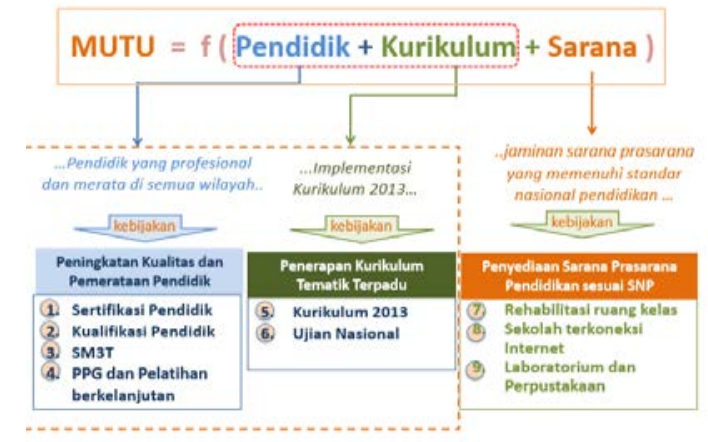

Gambar 2.1. Fungsi Pendidik, Kurikulum dan saran terhadap Mutu (kemendikbud, 2014)

Menurut paparan wakamendikbud mutu yang dihasilkan merupakan hasil dari fungsi pendidik dan kurikulum yang didukung oleh sarana pendidikan (2014). Hasil yang diharapkan oleh sebuah lembaga pendidikan adalah menghasilkan lulusan yang kompeten. Untuk dapat menghasilkan lulusan yang berkompeten maka diperlukan perangkat pembelajaran dan kurikulum yang tepat, dibutuhkan tenaga pendidik yang berkualitas dan kompeten di bidangnya sarana yang menunjang pendidikan. Berdasarkan fungsi tersebut maka potensi penyebab level pertama yang menyebabkan menurunnya capaian belajar selama kegiatan tatap muka terbatas dapat disebabkan oleh kesiapan sarana prasarana (machine), kurikulum atau materi (material), kesiapan pendidik yang didukung kesiapan siswa, orang tua dan guru (man). Dalam masa pandemic ini, untuk dapat menggelar pertemuan tatap muka terbatas, sekolah perlu menyiapkan prasarana sekolah (machine) untuk menunjang aktivitas pembelajaran offline dengan mengkondisikan ruang kelasnya supaya memenuhi persyaratan dari pemerintah yaitu kondisi kelas harus memenuhi jaga jarak minimal 1,5 meter, jumlah maksimal peserta didik per ruang kelas jenjang pendidikan anak usia dini (PAUD ) 5 (dari standar 15), peserta didik jenjang pendidikan dasar dan menengah 18 peserta Didik (dari standar 36).

Selain itu sekolah juga harus menyiapkan sarana dan prasarana tambahan yaitu sarana sanitasi dan kebersihan dan fasilitas kesehatan seperti area untuk cuci tangan dengan sabun dan air mengalir atau menggunakan hand sanitizer. Dari dashboard kesiapan proses belajar mengajar satuan pendidikan di masa pandemi covid-19 yang diterbitkan oleh kemendikbud (2021) diketahui bahwa baru $54,38 \%$ sekolah yang sudah merespon, Walaupun rata-rata sekolah yang merespon sudah siap sarana sanitasi dan kebersihan dan fasilitas kesehatan nya namun belum diketahui kondisi lebih dari 40\% yang belum merespon dan belum ada data resmi mengenai kesiapan dari kondisi kelas, dan sarana parasaran lain diluar sarana sanitasi dan fasiitas kesehatan yang juga berpotensi menimbulkan masalah apabila belum siap. Selain sarana dan prasarana, sesuai dengan fungi tersebut potensi penurunan capaian pembelajaran disebabkan karena materi pembelajaran yang tidak tersampaikan dengan baik kepada siswa (material). Hal ini sesuai dengan penelitian yang dilakukan oleh (Adha, Supriyanto, \& Timan, 2019) bahwa dari hasil penelitiannya disampaikan bahwa penyebab masalah menurunnya mutu lulusan MA Muhammadiyah 1 Plus Malang disebabkan oleh beberapa factor penyebab masalah yakni sumber daya manusia (man), sumber belajar (material), sarana dan prasarana (tools), dan metode pembelajaran. Dimana penyebab masalah pada faktor material adalah materi pelajaran masih ada yang belum tersampaikan, , dan materi pelajaran yang belum tuntas diajarkan.

Demikian juga dari sisi man baik itu persiapan guru, siswa dan orang tua. Persiapan guru sangatlah penting dikarenakan apabila guru kesulitan mengelola kegiatan pembelajaran secara offline maka dapat menyebabkan ketidaktercapaian hasil pembelajaran selama pembelajaran offline selain guru kesiapan siswa yang sebelumnya sekolah online yang belum beradaptasi dengan kebiasaan baru sekolah offline juga menjadi potensi penyebab timbulnya masalah demikian juga apabila orang tua belum mengizinkan siswa untuk mengikuti kegiatan sekolah offline maka dapat menjadai penyebab penurunan capaian belajar. Banyak orang tua yang belum mengizinkan anaknya mengikuti aktivitas pembelajaran tatap muka (offline) di sekolah karena masih merasa khawatir akan sangat berisiko jika siswa dibiarkan masuk kelas offline dalam kondisi saat ini.

Novita Sari Tanuwijaya, Witarsa Tambunan 
Setelah dipetakan penyebab level pertama maka dari kelima penyebab yang telah disebutkan diatas ditemukan bahwa penyebab utama dari menurunnya capaian belajar selama pembelajaran offline adalah materi pembelajaran (material) yang tidak tersampaikan dengan baik kepada siswa. Untuk itu dilakukan analisis lebih lanjut dari penyebab utama ini. Dari hasil analisis lebih lanjut terhadap penyebab utama di level satu ini, ditemukan bahwa hal ini disebabkan karena beberapa hal. Penyebab pertama yaitu sistem pembelajaran offline dilakukan secara bergiliran (shifting). Dengan system pembelajaran tatap muka terbatas (offline) dimana waktu pembelajaran terbatas, guru tidak mungkin memenuhi beban mengajar. Sehingga apabila siswa tidak proaktif dalam melakukan aktivitas pembelajaran maka siswa akan tertinggal. Penyebab lainnya adalah metode pembelajaran yang digunakan kurang efektif. Apabila metode yang diggunakan kurang efektif tentunya akan mempengaruhi penyampaian materi pembelajarannya.

Dalam penyampaian materi selama proses pembelajaran di masa pandemic covid-19 guru dapat melakukan inovasi menggunakan media pembelajaran yang telah tersedia saat ini baik secara online maupun offline (Sunarti, 2020). Guru perlu menyiapkan materi dan bahan pembelajaran dengan menggunakan berbagai media dan sumber pembelajaran dalam mendesain dan mengaplikasikan pembelajaran (Dirjen Guru dan Tenaga Kependidikan Kemendikbud, 2020). Hal ini sesuai dengan yang disampaikan Atsani (Atsani, 2020) bahwa dunia pendidikan menjadi berubah dalam proses pembelajaran dan pada aspek yang lainnya di sebabkan pandemi covid-19 ini. Sehingga dunia pendidikan juga harusa melakukan transformasi media pembelajaran untuk menyikapi nya.

Apabila dipetakan maka, pohon masalah secara keseluruhan dapat digambarkan sebagai berikut:

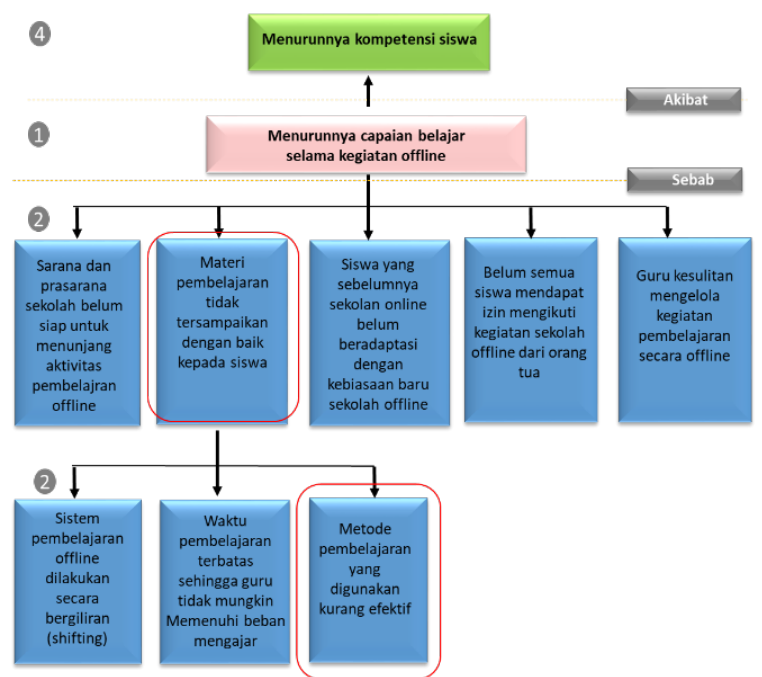

Dari pohon masalah yang dibuat maka dapat dipetakan pohon sasarannya sebagai berikut:

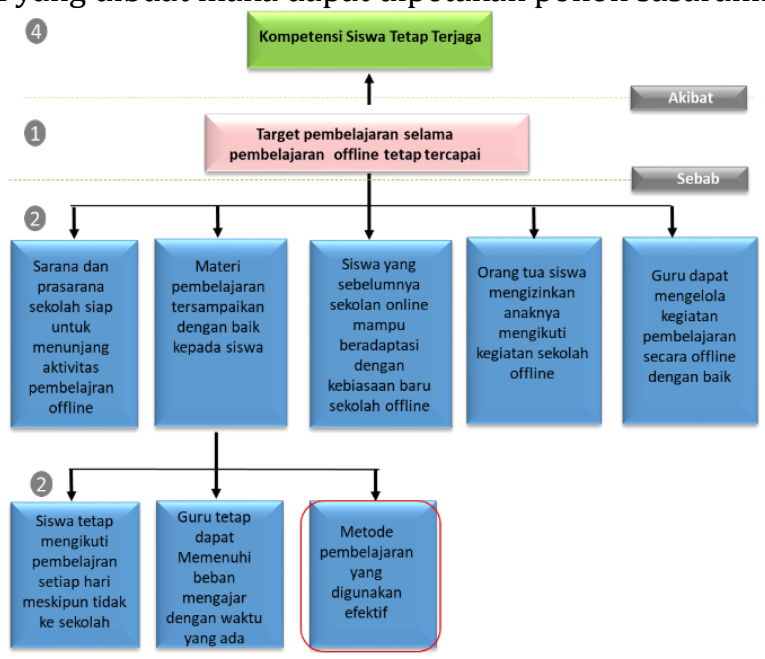

Novita Sari Tanuwijaya, Witarsa Tambunan 
Sasaran yang ingin dicapai adalah bagaimana agar kompetensi siswa tetap terjaga. Untuk menjaga kompetensi siswa maka target pembelajaran harus tercapai. Untuk mencapai target pembelajaran maka perlu ditunjang oleh beberapa faktor seperti kesiapan sarana dan prasarana, bagaimana menyampaikan materi pembelajaran dengan baik kepada siswa, bagaimana supaya siswa bisa beradaptasi dengan kebiasaan baru apabila sebelumnya sekolah online di rumah kini harus kembali sekolah dengan metode pembelajaran baru dan harus mengikuti protookol kesehatan. Selain siswa, guru perlu menyesuaikan diri dan mengelola kegiatan pembelajaran offline dengan baik agar target materi tercapai dan orang tua juga perlu memberi izin dan dukungan kepada anaknya dalam melakukan kegiatan pembelajara secara offline ini.

\section{KESIMPULAN}

Kesimpulan

Pelaksanaan pembelajaran tatap muka secara terbatas atau offline di satu sisi merupakan solusi namun di sisi lain memiliki ancaman berupa potensi masalah yang dapat timbul. Sasaran yang ingin dicapai adalah bagaimana agar kompetensi siswa tetap terjaga. Untuk menjaga kompetensi siswa maka target pembelajaran harus tercapai. Untuk mencapai target pembelajaran maka perlu ditunjang oleh beberapa faktor seperti kesiapan sarana dan prasarana, bagaimana menyampaikan materi pembelajaran dengan baik kepada siswa, bagaimana supaya siswa bisa beradaptasi dengan kebiasaan baru apabila sebelumnya sekolah online di rumah kini harus kembali sekolah dengan metode pembelajaran baru dan harus mengikuti protookol kesehatan. Selain siswa, guru perlu menyesuaikan diri dan mengelola kegiatan pembelajaran offline dengan baik agar target materi tercapai dan orang tua juga perlu memberi izin dan dukungan kepada anaknya dalam melakukan kegiatan pembelajara secara offline ini. Agar pembelajaran nya efektif maka beberapa alternative solusi yang dapat dilakukan adalah menyusun modul pembelajaran yang interaktif, menyusun kurikulum yang kolaboratif dan menggunakan metode blended learning. Berdasarkan hasil kajian literature, penggunaan metode blended learning merupakan alternative solusi yang paling baik untuk dilakukan. Berdasarkan beberapa penelitian yag dilakukan (Abdullah, 2018) diperoleh hasil bahwa pembelajaran dengan metode blended learning mempunyai dampak yang lebih efektif baik itu saat pembelajaran online ataupun pembelajaran tatap muka. Penggunaan Blended learning bisa di terapkan dengan memvariasikan komposisi antara pembelajaran online dan offline. Alternativealternatif solusi ini diharapkan dapat memberikan jawaban terhadap akar penyebab masalah yang ditemukan tadi mengenai metode pembelajaran yang kurang efektif. Apabila metode pembelajaran yang digunakan efektif tentunya materi pembelajaran tersampaikan dengan baik kepada siswa dan apabila materi pembelajaran tersampaikan dengan baik kepada siswa maka target pembelajaran selama pembelajaran offline tetap tercapai sehingga kompetensi siswa tetap terjaga.

Implikasi

Melalui metode blended learning dengan pemanfaatan beberapa media dan teknologi, maka dapat dipadukan antara pembelajaran jarak jauh dengan pertemuan langsung di kelas. Melalui metode ini siswa dilatih untuk dapat mandiri dalam melakukan akses dan mengimprove kemampuan serta pengetahuan teknologi yang dimilikinya. Tahapan dalam metode ini dimulai dengan siswa mencari informasi dari berbagai sumber, kemudian dari informasi tersebut siswa mendapat ide dan melakukan interpertasi pengetahuan yang didapat dan di tahap akhir siswa diharapkan dapat mengkonstruksikan serta mengkomunikasikan ide yang didapatnya. Metode ini menjadi solusi penyampaian materi pembelajaran selama pembelajaran offline yang efektif di masa pandemic ini.

Saran

Kebijakan pertemuan tatap muka terbatas sebagai solusi yang diambil untuk mengatasi kendala saat pembelajaran online dalam pelaksanaannya perlu dikombinasikan dengan metode pembelajaran yang tepat supaya materi atau target capaian belajar dapat tercapai dan siswa siswi dapat tetap mengikuti dan memahami materi pembelajaran yang disampaikan. Dimana selain mengikuti pembelajaran tatap muka terbatas di kelas siswa tetap melakukan proses pembelajaran di rumah dan ada pertemuan secara secara online juga di rumah. Sebagai dalam mengatasi potensi masalah yang data muncul maka dilakukan dengan aktivitas pembelajaran dengan metode blended 
learning, menyusun kurikulum implementatif berbasis kolaboratif, dan menyediakan modul pembelajaran yang interaktif dan kreatif untuk menunjang pembelajaran

\section{DAFTAR PUSTAKA}

1. Abdullah, W. (2018). Model blended learning dalam meningkatkan efektifitas pembelajaran. Fikrotuna, 855-866.

2. Adha, M. A., Supriyanto, A., \& Timan, A. (2019). Strategi peningkatan mutu lulusan madrasah menggunakan diagram fishbone. Tarbawi: Jurnal Keilmuan Manajemen Pendidikan, 11-22.

3. Asmoko, H. (2012). Asmoko, H. (2012). Balai Diklat Kepemimpinan.

4. Atsani, K. L. (2020). Transformasi media pembelajaran pada masa Pandemi COVID-19. AlHikmah: Jurnal Studi Islam, 82-93.

5. Dirjen Guru dan Tenaga Kependidikan Kemendikbud. (2020). Panduan Pembelajaran Jarak Jauh Bagi GURU selama Sekolah Tutup dan Pandemi Covid-19 Dengan Semangat Merdeka Belajar. Retrieved from http://pusdatin.kemdikbud.go.id: http://pusdatin.kemdikbud.go.id/wpcontent/uploads/2020/05/PANDUAN-PEMBELAJARAN-JARAK-JAUH-BELAJAR-DIRUMAHMASA-C-19.pdf

6. Dirjend, Pend dasar Menengah. (2017). Indikator Mutu Dalam penjaminan Mutu Pendidikan Dasar dan Menengah. Direktorat Jendral Pendidikan Dasar dan Menengah.

7. Handarini, O. I. (2020). Pembelajaran Daring Sebagai Upaya Study From Home (SFH) Selama Pandemi Covid 19. Jurnal Pendidikan Administrasi Perkantoran (JPAP), 502.

8. Herliandry, L. D., Nurhasanah , \& Enjelina, M. (2020). Pembelajaran Pada Masa Pandemi Covid19. Jurnal Teknologi Pendidikan, 65-70.

9. Ini Kendala Sekolah Tatap Muka Saat Pandemi Covid-19. (2020, Agustus 20). Retrieved from https://www.kompas.tv/amp/article/102920/videos/ini-kendala-sekolah-tatap-muka-saatpandemi-covid-19

10. Kemendikbud. (2003). Undang-undang Republik Indonesia No 20 Tahun 2003. Retrieved from lppks.kemdikbud.go.id:

http://lppks.kemdikbud.go.id/uploads/pengumuman/uu_no_20_tahun_2003.pdf

11.kemendikbud. (2014, Januari 24). www.kemdikbud.go.id. Retrieved from Press Workshop: Implementasi Kurikulum 2013: https://www.kemdikbud.go.id/kemdikbud/dokumen/Paparan/Paparan\%20Mendikbud\%20pa da\%20Workshop\%20Pers.pdf

12. Kemendikbud. (2014). www.kemdikbud.go.id. Retrieved from Press Workshop: Implementasi Kurikulum

https://www.kemdikbud.go.id/kemdikbud/dokumen/Paparan/Paparan\%20Mendikbud\%20pa da\%20Workshop\%20Pers.pdf

13. Kemendikbud. (2020, Mei). buku-saku-panduan-pembelajaran-di-masa-pandemi-covid19. Retrieved from https://www.kemdikbud.go.id/: https://www.kemdikbud.go.id/main/blog/2020/06/buku-saku-panduan-pembelajaran-dimasa-pandemi-covid19

14. Kemendikbud. (2020). Pemerintah Daerah Diberikan Kewenangan Penuh Tentukan Izin Pembelajaran Tatap Muka. Retrieved April 08, 2021, from Kementrian Pendidikan dan Kebudayaan: $\quad$ https://www.kemdikbud.go.id/main/blog/2020/11/pemerintah-daerahdiberikan-kewenangan-penuh-tentukan-izin-pembelajaran-tatap-muka

15. Kemendikbud. (2020). Penyesuaian Kebijakan Pembelajaran di Masa Pandemi COVID19. Retrieved from https://covid19.go.id/storage/app/media/Protokol/2020/Agustus/20200807pembelajaran-di-masa-covid-19-2.pdf

16. Kemendikbud. (2021, Juni 4). http://sekolah.data.kemdikbud.go.id. Retrieved from DASHBOARD KESIAPAN PROSES BELAJAR MENGAJAR SATUAN PENDIDIKAN DI MASA PANDEMI COVID-19: http://sekolah.data.kemdikbud.go.id/kesiapanbelajar/dashboard

17. Latip, A. (2020). Peran literasi teknologi informasi dan komunikasi pada pembelajaran jarak jauh di masa pandemi Covid-19. EduTeach: Jurnal Edukasi dan Teknologi Pembelajaran, 108-116.

Novita Sari Tanuwijaya, Witarsa Tambunan 
18. Sekolah tatap muka: Semester genap dimulai, sejumlah daerah memutuskan terus gelar pembelajaran daring. (2021, Januari 4). Retrieved from https://www.bbc.com/indonesia/indonesia-55525851

19. Suhelayanti. (2019). Analisis Kebijakan Pendidikan. Lentera Indonesian Journal of Multidisciplinary Islamic Studies, 11-26.

20. Sukarman Purba, d. (2021). Analisis Kebijakan Pendidikan. Yayasan Kita Menulis.

21.Sunarti, S. (2020). Retrieved from Media Pembelajaran di masa Pandemi covid-19. 